\title{
IDENTIFIKASI FAKTOR-FAKTOR YANG MEMPENGARUHI PERUBAHAN HABITAT BENTIK DI SEBAGIAN PULAU WEH TAHUN 2010 dan 2015
}

\author{
M. Taufik Rahmadi', Hartono ${ }^{2}$, Nurul Khakhim ${ }^{3 *}$ \\ 1 Penginderaan Jauh, Fakultas Geografi,Universitas GadjahMada, Yogyakarta \\ ${ }^{2,3}$ Kartografi dan Penginderaan Jauh, Fakultas Geografi,Universitas Gadjah Mada, Yogyakarta
}

Diterima Agustus, Disetujui Oktober 20I7; Dipublikasikan Jdesember 2017

\begin{abstract}
Abstrak
Wilayah pesisir dan kelautan Indonesia merupakan daerah yang memiliki potensi sumber daya alam yang besar dan dapat dimanfaatkan untuk pembangunan. Sebagai sebuah negara kepulauan terbesar di dunia, Indonesia memiliki 17.508 pulau yang sebagian yaitu 13.466 pulau telah berkoordinat dan bernama, garis pantai sepanjang $99.093 \mathrm{~km}^{2}$, dan luas wilayah perairan $6.315 .222 \mathrm{~km}^{2}$ (BIG, 2015). Kelestarian habitat bentikdapatmengalamiperubahan yang disebabkan oleh berbagai factor seperti kecerahan, suhu, salinitas, sedimentasi, $\mathrm{pH}$, dan bencana alam. Faktorfaktor tersebut menjadikan habitat bentik mengalami degradasi hingga mencapai kondisi yang tidak memungkinkan bagi habitat bentik untuk memulihkan kondisinya secara alami. Dahuriet al., 1996 dalam Supriharyono, 2000 mengemukakan kadar kualitas yang mampu diterima oleh habitat bentik yaitu $\mathrm{pH}(6,8-7,5)$, suhu $\left(25^{\circ}-30^{\circ}\right)$, dansalinitas $\left(34^{\circ} \% 0-36^{\circ} \%\right)$. Penelitian ini memberikan hasil yaitu kadar $\mathrm{pH}$ memiliki nilai rata-rata yaitu 8.14 , suhu permukaan laut memiliki nilai ratarata yaitu $29.26^{\circ} \mathrm{C}$, salinitas air laut memiliki nilai rata-rata yaitu $36^{\circ} \%$, dimana nilai rata-rata kadar kualitas air tersebut merupakan nilai maksimal yang dapat ditoleransi oleh habitat bentik.
\end{abstract}

Kata Kunci : Habitat Bentik, Faktor Kelestarian, Pulau Weh.

\section{Abstract}

Coastal areas and marine Indonesia is an area that has great natural resource potential and can be utilized for development. As the largest archipelagic country in the world, Indonesia has 17,508 islands of which 13,466 islands have been coordinated and named, 99,093 $\mathrm{km} 2$ of coastline, and water area of 6,315,222 $\mathrm{km} 2(B I G, 2015)$. The preservation of benthic habitats can lead to changes caused by various factors such as brightness, temperature, salinity, sedimentation, $\mathrm{pH}$, and natural disasters. These factors make the benthic habitat degraded until it reaches a condition that does not allow the benthic habitat to restore its condition naturally. Dahuriet al., 1996 in Supriharyono, 2000 suggests levels of quality that are acceptable to benthic habitats, ie $p H$ (6.8-7.5), temperature (250-300), and salinity (340 / oo-360 / o). This research gives the result that $\mathrm{pH}$ content has average value that is 8.14 , sea surface temperature has average value that is 29.260 C, salinity sea water has average value that is 360/00, where the average value of water quality level is the maximum value that the benthic habitat can tolerate.

Keywords: Bentik Habitat, Sustainability Factor, Pulau Weh.

How to Cite : Rahmadi,T. (2017). Analisis Identifikasi Faktor-Faktor Yang Mempengaruhi Perubahan Habitat Bentik Di Sebagian Pulau Weh Tahun 2010 Dan 20155 (2): 1-5

${ }^{*}$ Corresponding author:

P-ISSN-2549-9165

E-mail: taufikrahmadil4@gmail.com

e-ISSN -2580-2011 


\section{PENDAHULUAN}

Wilayah pesisir dan kelautan Indonesia merupakan daerah yang memiliki potensi sumber daya alam yang besar dan dapat dimanfaatkan untuk pembangunan. Sebagai sebuah negara kepulauan terbesar di dunia, Indonesia memiliki 17.508 pulau yang sebagian yaitu 13.466 pulau telah berkoordinat dan bernama, garis pantai sepanjang $99.093 \mathrm{~km}^{2}$, dan luas wilayah perairan 6.315.222 $\mathrm{km}^{2}$ (BlG, 2015). Secara garis besar sumber daya wilayah pesisir dan lautan terdiri atas tiga kelompok yaitu (1) sumber daya dapat pulih meliputi hutan bakau, terumbu karang, padang lamun, rumput laut, sumber daya perikanan laut, dan bahan-bahan bioaktif, (2) sumber daya tidak dapat pulih meliputi minyak bumi, gas alam, dan seluruh mineral dan geologi, dan (3) jasa-jasa lingkungan meliputi fungsi kawasan pesisir dan lautan sebagai tempat rekreasi dan pariwisata, media transportasi dan komunikasi, sumber energi, sarana pendidikan dan penelitian, pertahanan keamanan, penampungan limbah, pengatur iklim, dan sistem penunjang kehidupan ekologi serta fungsi ekologis lainnya (Dahuri et al., 1996; Syah, 2010; UU No. 1 Tahun 2014).

Menurut Syah (2010) dalam pengelolaan wilayah pesisir dan kelautan masih mengalami masalah-masalah yang tidak mudah. Beberapa masalah mendasar yang dihadapi antara lain (1) pemanfaatan wilayah pesisir yang tidak seimbang, (2) pembangunan yang tidak memperhatikan tata ruang, (3) sumber daya manusia yang terbatas dalam mengelola dan memanfaatkan secara optimal, (4) kehidupan masyarakat pesisir yang memiliki standar hidup dibawah garis kemiskinan sehingga memaksa mengeksploitasi sumber daya melebihi potensi lestari, (5) sarana dan prasarana di sebagian wilayah pesisir yang masih terbatas, dan (6) kurangnya investasi pada sektor pesisir dan kelautan.

Menurut Barus (2000) habitat bentik (benthos) merupakan organisme air yang hidupnya terdapat pada substrat dasar suatu perairan yang masih dapat ditembus oleh cahaya matahari, baik yang bersifat sesil (melekat) maupun vagil (bergerak bebas) dan terbagi pada zona di atas substrat dasar perairan dan zona di dalam substrat dasar perairan. Habitat bentik juga dibedakan berdasarkan sifat hidupnya yaitu organisme habitat bentik yang bersifat tumbuhan (fitobenthos) dan organisme habitat bentik yang bersifat hewan (zoobenthos).
Kelestarian habitat bentik dapat mengalami perubahan yang disebabkan oleh berbagai faktor seperti kecerahan, suhu, salinitas, sedimentasi, $\mathrm{pH}$, dan bencana alam. Faktor-faktor tersebut menjadikan habitat bentik mengalami degradasi hingga mencapai kondisi yang tidak memungkinkan bagi habitat bentik untuk memulihkan kondisinya secara alami. Perubahan organisme habitat bentik berkaitan dengan perubahan struktur dan fungsi dari eksosistem habitat bentik tersebut. Untuk tetap menjaga kelestarian organisme habitat bentik diperlukan pengelolaan yang berkesinambungan. Dalam UU No 1 Tahun 2014 tentang Pengelolaan Wilayah Pesisir dan Pulau-Pulau Kecil menyatakan pengelolaan wilayah pesisir dan pulau-pulau kecil merupakan suatu proses perencanaan, pemanfaatan, pengawasan, dan pengendalian sumber daya pesisir dan pulau-pulau kecil antar sektor, antara pemerintah pusat dan pemerintah daerah, antara organisme darat dan laut, serta antara ilmu pengetahuan dan manajemen untuk meningkatkan kesejahteraan masyarakat. Pengelolaan ini pada hakekatnya merupakan suatu proses pemantauan/pengontrolan tindakan manusia, agar pemanfaatan sumber daya alam terutama organisme habitat bentik dapat dilakukan secara bijaksana dengan mengindahkan kaidah kelestarian lingkungan.Penelitian ini bertujuan untukmenganalisis faktor-faktor yang berpengaruh terhadap perubahan habitat bentik di Pulau Weh tahun 2010 dan 2015.

\section{METODE PENELITIAN}

Penelitian ini dilakukan di sebagian PulauWeh yang secara administrative terletak di wilayah Provinsi Aceh. Secara geografis lokasi penelitian terletak antara $95^{\circ} 12^{\prime} 0^{\prime \prime}$ $95^{\circ} 16^{\prime} 0^{\prime \prime}$ BT dan $5^{\circ} 51^{\prime} 0^{\prime \prime}$ - $5^{\circ} 55^{\prime} 0^{\prime \prime}$ LU. Dari segi geografis Indonesia, wilayah Pulau Weh masuk dalam administrasi Kota Sabang dan berbatasan langsung dengan Negara tetangga yaitu Malaysia, Thailand, dan India. Kota Sabang terdiri atas lima pulau yaituPulau Rondo, PulauKlah, PulauCeulako, Pulau Rubiah, danPulau Weh sebagai pulau terbesar. Kota Sabang terbagi atas 2 $\begin{array}{llll}\text { kecamatan dan } & 18 & \text { kelurahan }\end{array}$ (sabangkota.go.id, 2016). 
Penelitian ini menggunakan data kualitas air untuk menganalisis faktor-faktor yang berpengaruh terhadap perubahan habitat bentik berdasarkan hasil pemetaan distribusi dan perubahan komposisi habitat bentik di Pulau Weh menggunakancitra Worldview-2 perekaman 17 Januari 2010 dan 7 Desember
2015 dengan tingkat akurasi pemetaan sebesar $69.23 \%$. Pemetaan distribusi habitat bentik di sebagian Pulau Weh tahun 2010 dan 2015 menunjukkan adanya perubahan luasan habitat bentik. Untuk lebih jelasnya dapat dilihat pada Tabel 2.1 berikut ini.

Tabel 2.ı. Distribusi Habitat Bentik di Sebagian Pulau Weh

Tahun 2010 dan 2015

\begin{tabular}{|l|l|c|l|l|l|}
\hline \multirow{2}{*}{ No. } & SkemaKlasifikasi & \multicolumn{4}{l|}{ Luas Habitat Bentik (Ha) } \\
\cline { 3 - 6 } & Habitat Bentik & $\mathbf{2 0 1 0}$ & $\%$ & $\mathbf{2 0 1 5}$ & $\%$ \\
\hline 1. & TerumbuKarang & 155,05 & 77,15 & 161,25 & 80,52 \\
\hline 2. & Lamun & 3,10 & 1.54 & 0 & 0 \\
\hline 3. & KarangMati $($ Rubble) & 31,52 & 15.68 & 31,94 & 15,94 \\
\hline 4. & SubstratDasarTanpaVegetasi & 11,30 & 5,62 & 7,07 & 3,53 \\
\hline Jumlah & 200.97 & 100 & 200.26 & 100 \\
\hline
\end{tabular}

\section{Pemrosesan Data Awal}

Sebelummenguji kualitas air untuk menganalisis faktor-faktor yang berpengaruh terhadap perubahan habitat bentik, dilakukan pemetaan distribusi habitat bentik terlebih dahulu. Setelah mendapatkan hasil distribusi habitat bentik tahun 2010 dan 2015 selanjutnya dilakukan analisis untuk mengetahui perubahan distribusi habitat bentik.

\section{Surveilapangan}

Survei lapangan dilakukan pada tanggal 19-23 November 2016. Survei lapangan dilakukan di sebagian Pulau Weh dengan menggunakan metode photo transect yang dikembangkan oleh Roeflsema et al. (2009). Lokasi sampel lapangan ditentukan secara visual berdasarkan peta satuan pemetaan yang telah di proses sebelumnya dengan mengambil titik sampel sebanyak 15 titik.

Survei lapangan mengambil sampel kualitas air yang terdiri atas suhu permukaan laut, tingkat salinitas, dan kadar $\mathrm{pH}$ sebagai parameter faktor kelestarian habitat bentik, serta pengaruh pasang dan surut. Skema kelas habitat bentik pada penelitian ini mengacu pada Wicaksono (2016). Skema kelas habitat bentik terdiri atas terumbu karang, lamun, karang mati (rubble), dan substrat dasar tanpa vegetasi. Penentuan kelas habitat bentik di lihat berdasarkan luasan habitat bentik di lapangan yaitu luas distribusi habitat bentik berdasarkan photo transect memiliki luas area $50 \%$.

\section{HASIL DAN PEMBAHASAN}

Faktor kelestarian habitat bentikmerupakanfaktor-faktor yang dapatmempengaruhikelangsunganhidup habitat bentik. Faktor-faktorkelestarianbaik proses biologis, fisika, dankimiapadasuatuperairanmemilikiperanan yang sangatpentinguntukkelangsunganhidup habitat bentik. Padapenelitianini parameter faktorkelestarian habitat bentikyaitu $\mathrm{pH}(6,8$ $7,5)$, suhu $\left(25^{\circ}-30^{\circ}\right)$, dansalinitas $\left(34^{\circ} \% 0-36^{\circ} \%\right)$ (Dahuriet al., 1996 dalamSupriharyono, 2000).

$\mathrm{pH}$

$\mathrm{pH}$ merupakan derajat keasaman yang digunakan untuk menyatakan tingkat keasaman atau kebasaan yang terdapat pada suatu larutan. Tingkat keasaman yang baik untuk kelangsungan hidup habitat bentik yaitu berkisar antara 6,8-7,5. Dari hasil pengukuran kadar $\mathrm{pH}$ air laut di lokasi penelitian, kadar $\mathrm{pH}$ memiliki nilai rata-rata yaitu 8,14. Berdasarkan tingkat keasaman, kadar $\mathrm{pH} 8,14$ tersebut melebihi batas maksimal dari kadar $\mathrm{pH}$ yang 
dapat ditolerasi untuk kelangsungan hidup habitat bentik. Kadar pH pada survei lapangan penelitian ini memiliki nilai terendah 7,97 dan tertinggi 8,33.

Menurut CoralWatch (2009) faktor yang paling mempengaruhi tingginya $\mathrm{pH}$ air laut pada daerah tropis adalah konsentrasi karbon dioksida di atmosfer, hal ini terjadi karena karbon dioksida yang dilepaskan oleh laut kembali ke atmosfer. Laju penyerapan karbon dioksida dilautan tergantung dari konsentrasinya di atmosfer dan berkaitan erat dengan suhu laut, arus, dan tingkat aktivitas biologis yang terjadi di lautan. Karbon dioksida dari atmosfer akan terlarut ketika menyentuh permukaan laut, sebagian karbon dioksida terlarut akan bereaksi dengan air laut membentuk asam karbonat, dan sisanya tetap menjadi gas terlarut yang digunakan oleh habitat bentik atau organisme laut lainnya untuk melakukan fotosintesis.

\section{Suhu}

Suhu memiliki peranan yang sangat penting terhadap proses kelangsungan hidup organisme suatu perairan. Kisaran suhu yang dapat di toleransi untuk kelangsungan hidup habitat bentik yaitu $25^{\circ}-30^{\circ}$. Dari hasil pengukuran suhu permukaan air laut di lokasi penelitian, suhu permukaan laut memiliki nilai rata-rata yaitu $29.26^{\circ} \mathrm{C}$ yang merupakan batas suhu maksimal yang dapat di toleransi oleh habitat bentik. suhu pada suvei lapangan ini memiliki nilai terendah $29^{\circ} \mathrm{C}$ dan tertinggi $30^{\circ} \mathrm{C}$. Perubahan suhu dapat mempengaruhi proses kelangsungan hidup habitat bentik yang berpengaruh terhadap proses kimia, fisika, dan biologi pada badan air. Perubahan suhu dalam jangka waktu yang panjang dengan nilai perubahan $1^{\circ} \mathrm{C}-2^{\circ} \mathrm{C}$ akan memberikan tekanan pada habitat bentik untuk memutih, dimana habitat bentik akan kehilangan zooxanthela dari dalam jaringan binatang karang yang merupakan biota penting untuk pertumbuhan habitat bentik.

\section{Salinitas}

Salinitas merupakan tingkat keasinan atau kadar garam yang terlarut dalam air. Habitat bentik hidup subur pada kisaran salinitas antara $34 \%$ oo-36\% Dari hasil pengukuran salinitas air laut di lokasi penelitian, salinitas air laut memiliki nilai ratarata yaitu $36 \%$, yang merupakan batas akhir toleransi untuk kelangsungan hidup habitat bentik. salinitas pada survei lapangan penelitian ini, memiliki nilai terendah $34^{\circ} \%$ dan tertinggi $40 \%$. Habitat bentik memiliki toleransi terhadap tingkat salinitas yang berbeda-beda, namun salinitas yang optimal untuk pertumbuhan habitat bentik yaitu pada kisaran $35 \%$

CoralWatch (2009) mengemukakan salinitas dapat berubah-ubah akibat bertambah dan berkurangnya molekul-molekul air melalui proses penguapan dan hujan. Salinitas meningkat apabila laju penguapan di suatu daerah lebih besar dari pada hujan, sedangkan salinitas berkurang apabila hujan lebih besar dari penguapan.

\section{Pengaruh Pasang Surut}

Pasang surut di Pulau Weh merupakan pasang surut harian ganda (semi diurnal tide) yaitu pada satu hari dalam waktu 24 jam terjadi dua kali pasang dan dua kali surut, dengan pasang rata-rata $1,2-1,4 \mathrm{~m}$ dan surut rata-rata 0,2-0,4 $\mathrm{m}$. Pasang surut memiliki peran penting terhadap kehidupan habitat bentik. Pada saat surut, organisme laut dapat terpapar pada kondisi terbuka. Dengan menurunnya ketinggian air, gelombang menghantam bebatuan dan menyapu organisme yang tidak memiliki pegangan kuat pada substrat dasar perairan, sehingga habitat bentik akan mengalami kerusakan dan berpengaruh pada proses lainnya yaitu proses fisika, kimia, dan biologi. Pasang surut juga mempengaruhi organisme habitat bentik terpapar cahaya matahari yang berlebihan. 


\section{Simpulan}

Perubahan komposisi habitat bentik dapat terjadi karena berbagai faktor kelestarian seperti aktivitas manusia dan bencana alam. Hal ini dikarenakan habitat bentik memiliki batas toleransi yang berbedabeda terhadap faktor kelestarian. Beberapa faktor alam yang berpengaruh terhadap perubahan komposisi habitat bentik antara lain suhu, salinitas, dan kadar $\mathrm{pH}$ di luar batas toleransi habitat bentik. Sedangkan faktor aktivitas manusia yang merusak berupa kegiatan pariwisata bawah air yang tidak memperhatikan kondisi habitat bentik dan pembuangan bahan bakar kapal. Salah satu faktor perubahan habitat bentik dari aktivitas manusia bertujuan untuk memulihkan kondisi habitat bentik dan ekosistem dasar perairan yaitu penanaman terumbu karang. Penanaman terumbu karang juga berfungsi untuk memberikan perlindungan dan pemanfaatan sumber daya alam yang berkelanjutan.

\section{Daftar Pustaka}

Barus, T. A. (2000). Pengantar Limnologi. Medan: Jurusan Biologi FMIPA USU.

Dahuri, R., Rais, J., Ginting, S. P., \& Sitepu, M. J. (1996). Pengelolaan Sumber Daya Wilayah Pesisir dan Lautan Secara Terpadu. Jakarta: Pradnya Paramita.

Syah, A. F. (2010). Penginderaan Jauh dan Aplikasinya di Wilayah Pesisir dan Lautan. Jurnal Kelautan. Vol. 3. pp. 1907-9931.

Supriharyono. (2000). Pengelolaan Ekosistem Terumbu Karang. Jakarta: Djambatan.

Uu. No 1 Tahun 2014 Tentang Perubahan Atas UU No. 27 Tahun 2007 Tentang Pengelolaan Wilayah Pesisir dan PulauPulau Kecil.

Roelfsema, C. M., \& Phinn, S. R. (2009). A Manual for Conducting Georeferenced Photo Transects Surveys to Assess the Benthos of Coral Reef and Seagrass Habitats. Queensland: Centre for Remote Sensing \& Spatial Information Science, School of Geography, Planning \& Environmental Management, University of Queensland.
RSNI3. (2010). Basis Data Spasial Oseanografi : Suhu, Salinitas, Oksigen Terlarut, Derajat Keasaman, Turbiditas, dan Kecerahan. Badan Standardisasi Nasional. RSNI3. 7644.2010

Http://www.bappeda.sabangkota.go.id (diakses Rabu 16 September 2015 Pukul. 14.15 WIB).

Http://www.bakosurtanal.go.id. Pentingnya Informasi Geospasial Untuk Menata Laut Indonesia. Berita Surta. (diakses Rabu 16 September 2015 Pukul. 14.15 WIB).

Https://oceancolor.gsfc.nasa.gov/cms/ (diakses 20 November 2016 Pukul 08.00 WIB). 